\title{
FOREIGN DIRECT INVESTMENT IN TURKEY IN THE FRAMEWORK OF CANDIDACY TO THE EU
}

\author{
A.Kadir Mercül ${ }^{*}$
}

\begin{abstract}
Although the level of FDI exceeded that of the previous decade, throughout 1990 s Turkey felt behind the rest of the world. The paper, from the theoretical perspective and also by using the results of the interviews with foreign businessmen in Turkey provides some insight into the reasons for the lack of FDI in Turkey.

The views of the foreign investors are investigated for the motives of FDI, for the characteristics of the investment environment in Turkey and also for the role of the government to promote FDI in Turkey. The results of the interviews show that country specific factors are of greater importance in the foreign firms' decision to invest in Turkey and that the government has an important role in maintaining economic and political stability, in improving Turkey's negative image abroad and in providing effective investment incentives. The relationship between FDI and Labour markets in Turkey, Inflation in Turkey, and Trade Policy in Turkey are amongst the other topics investigated.

The views of the foreign investors regarding the growth potential of the country in the region as well as the effects of Turkey's Customs Union and possible membership to $E U$ are also sought. The paper comments on the internal and external reasons behind the inability of Turkey in attracting FDI and the factors that need to be changed for Turkey to attract FDI.
\end{abstract}

\footnotetext{
*Assoc.Prof. Dr., İstanbul University Faculty of Economics
} 


\section{FDI in Turkey}

The Foreign Direct Investment Policy of Turkey as a candidate for EU membership is now of greater importance than it was two decades ago. The history of FDI in Turkey accelerated in the early 1980s within the framework of export-oriented trade policy. As is well known, the economic structure was based mainly on import substitution before the famous " $24^{\text {th }}$ of January decisions." Through reforms to the existing foreign investment law, Turkey's FDI policy targeted opening the domestic market to global competition in the long term. These changes included reforms aimed at liberalizing foreign trade, removing price controls, reducing subsidies and tariffs, promoting exports, reducing the role of the public sector in the economy, reforming the system of taxation, encouraging foreign investments and creating a more independent Central Bank.

After 1980, steps were taken to replace the import substitution strategy with an outward-oriented export based strategy. The new strategy is backed up by deregulation concerning exchange rates, interest rates, and product prices of state enterprises. In 1986, a new Foreign Investment Department has been established for foreign investment permissions. There were; the removal of minimum export requirements, the introduction of $100 \%$ foreign ownership for all foreign investors in all sectors, more favorable tax legislation for foreign investment and an increased use of the build operate transfer program (BTO). These changes had quite a large impact on increasing the level of FDI in Turkey, from the level of \$13.6 million in 1970 s to over $\$ 1$ billion per year in 1990s. (Table 1). 


\section{Table 1: FDI in Turkey}

\begin{tabular}{|l|l|l|l|}
\hline Years & Firms & FDI (US\$mn) & $\begin{array}{l}\text { Cumulative FDI (US\$ } \\
\text { mn) }\end{array}$ \\
\hline $\begin{array}{l}\text { Until } \\
1979\end{array}$ & NA & NA & 228 \\
\hline 1980 & 78 & 35 & 263 \\
\hline 1981 & 109 & 141 & 404 \\
\hline 1982 & 147 & 103 & 507 \\
\hline 1983 & 166 & 87 & 594 \\
\hline 1984 & 235 & 162 & 756 \\
\hline 1985 & 408 & 158 & 914 \\
\hline 1986 & 619 & 170 & 1084 \\
\hline 1987 & 806 & 239 & 1323 \\
\hline 1988 & 1172 & 488 & 1811 \\
\hline 1989 & 1525 & 855 & 2666 \\
\hline 1990 & 1856 & 1005 & 3671 \\
\hline 1991 & 2123 & 1041 & 4712 \\
\hline 1992 & 2330 & 1242 & 5954 \\
\hline 1993 & 2554 & 1016 & 6970 \\
\hline 1994 & 2830 & 830 & 7800 \\
\hline 1995 & 3161 & 1127 & 8927 \\
\hline 1996 & 3582 & 964 & 9891 \\
\hline 1997 & 4068 & 1032 & 10923 \\
\hline 1998 & 4533 & 976 & 11899 \\
\hline 1999 & 4950 & 817 & 12716 \\
\hline & & & \\
\hline
\end{tabular}

Source: www.treasury.gov.tr

The level of Turkey's share of total FDI in the 1990s, although accelerated compared to the previous decade, felt behind the rest of the world. As a percentage of GDP, FDI in Turkey stayed almost steady at the levels of $0.2 \%$ to $0.3 \%$ in ten years time between 1988 and 1998 , despite the customs union in 1996 with the EU. 
In comparison, the ratio of a sample of other developing countries grew from $0.54 \%$ in 1988 to almost $2 \%$ by 1998 . In the fellow EU candidates, the level of FDI investment that was next to zero in 1988 grew to $2.3 \%$ of GDP in 1998.

\section{Table 2: Comparative FDI and GDP Rates}

\begin{tabular}{|c|c|c|c|c|c|c|}
\hline \multirow[t]{2}{*}{ Developing Countries } & \multicolumn{2}{|c|}{$\begin{array}{c}\text { FDI as \% of } \\
\text { GDP }\end{array}$} & \multicolumn{2}{|c|}{ GDP Growth } & \multirow{2}{*}{$\begin{array}{c}\begin{array}{c}\text { PPP } \\
\text { in } \\
\text { GDP }\end{array} \\
1998\end{array}$} & \multirow{2}{*}{$\begin{array}{c}\begin{array}{c}\text { Pop. } \\
\text { Growth }\end{array} \\
\text { 1998- } \\
\text { 2015E } \\
\end{array}$} \\
\hline & 1988 & 1998 & $\begin{array}{l}1980- \\
1990\end{array}$ & $\begin{array}{l}1990- \\
1998\end{array}$ & & \\
\hline World & 1.7 & 3.8 & 3.2 & 2.4 & 4890 & 1.1 \\
\hline Low income & 0.2 & 0.9 & 6.6 & 7.3 & 520 & 1.3 \\
\hline Exd. China\&India & NA & NA & 4.1 & 3.6 & 370 & 1.9 \\
\hline Middle income & 0.4 & 1.6 & 2.6 & 1.9 & 2990 & 1.0 \\
\hline Lower middle income & 0.3 & 1 & NA & -1.3 & 1740 & 0.9 \\
\hline Upper middle income & 0.5 & 2.2 & 2.7 & 3.9 & 4870 & 1.1 \\
\hline Low\&middle income & 0.3 & 1.3 & 3.5 & 3.3 & 1250 & 1.2 \\
\hline East Asia\&Pacific & 0.4 & 1.3 & 8 & 8.1 & 990 & 0.8 \\
\hline Europe and Central Asia & NA & 1 & NA & -4.3 & 2200 & 0.1 \\
\hline Latin America\& Carib. & 0.5 & 2.5 & 1.6 & 3.7 & 3860 & 1.3 \\
\hline Middle East\&N. Africa & 0.3 & 0.9 & 2 & 3. & 2030 & 1.8 \\
\hline South Asia & 0 & 0.1 & 5.7 & 5.7 & 430 & 1.5 \\
\hline Sub Saharan Africa & 0.3 & 0.7 & 1.8 & 2.2 & 510 & 2.2 \\
\hline High income & 2.6 & 5.7 & 3.1 & 2.1 & 25480 & 0.3 \\
\hline Europe EMU & 2.1 & 6.1 & NA & NA & 22350 & -0.1 \\
\hline EU candidates & 0.0 & 2.3 & 2.4 & -0.6 & 3735 & -0.2 \\
\hline Bulgaria & 0 & 1.0 & 3.4 & -3.3 & 1220 & -0.7 \\
\hline Cyprus & NA & NA & NA & NA & 11920 & NA \\
\hline Czech Republic & 0 & 2.0 & 1.7 & -0.2 & 5150 & -0.2 \\
\hline Estonia & 0 & 6.0 & 2.2 & -2.1 & 3360 & -0.5 \\
\hline Hungary & 0 & 2.3 & 1.3 & -0.2 & 4510 & -0.4 \\
\hline Latvia & 0 & 3.1 & 3.5 & -8.5 & 2420 & -0.8 \\
\hline Lithuania & 0 & 3.9 & NA & -5.2 & 2540 & -0.1 \\
\hline Malta & NA & $\mathrm{NA}$ & NA & NA & 10100 & NA \\
\hline Poland & 0 & 2.5 & 1.8 & 4.5 & 3910 & 0 \\
\hline Romania & 0 & 1.6 & 0.5 & -0.6 & 1360 & -0.3 \\
\hline Slovak Republic & 0 & 1.7 & 2 & 0.6 & 3700 & 0.1 \\
\hline Slovenia & 0 & 0.6 & NA & 1.4 & 9760 & -0.2 \\
\hline Turkey & 0.2 & 0.3 & 5.4 & 4.1 & 3160 & 1.2 \\
\hline
\end{tabular}

Source: www.worldbank.org 


\section{The main factors that affect the level of FDI in Turkey}

There are certain factors that affect the level of FDI in each country. The results of the research carried shows that almost none of the investors came to Turkey with the intention of utilizing currency differences as the "capital flow theory" suggests ${ }^{1}$. Hence, country specific factors rather than company specific factors were of greater importance in the firm's decision to invest in Turkey.

According to the foreign investors, there are three overriding reasons for entering the Turkish market that are categorized as market seeking motives. They were as follows;

- Geographical position of Turkey,

- Presence of a large domestic market,

- Growth potential of Turkish economy

As other underlying factors, it has been mentioned that, Turkey has created one of the most welcoming legal environment that should attract foreigner interest ${ }^{2}$. Turkey has the youngest workforce in Europe, and the fact that Turkey is a strong supply of new workers for the aging western European markets has also been mentioned.

\section{The General Outlook of the Economic Situation for Investors}

There are specific motivating factors for inflows of FDI to Turkey, but the characteristics of the economic situation does not seem to be facilitating. According to the foreign investors, the following were seen as the most important characteristics of Turkey's Investment environment .

- Chronic inflation

- Currency devaluation

- High Interest Rates

- Tax rates 


\section{Chronic Inflation}

Over the past two decades, high inflation has been a problem in Turkey, causing a number of problems for firms doing business in Turkey. Inflation makes it very difficult to create long-term plans and becomes a major problem for company's receivables.

\section{Currency devaluation}

When currency devaluation, highlighted as another important characteristic of the economic environment fails to track inflation, the real value of TL becomes unstable and risky. The level of FDI had considerably increased in 2000, however, the crisis and the currency devaluation of February 2001 has been one of the most discouraging factors.

\section{High Interest Rates}

In an economy with volatile inflation, interest rates are accordingly very high to compensate lenders for this risk. With high real interest rates, access to domestic financing becomes difficult if not impossible and long term financing is completely unavailable.

\section{Tax Rates}

Data obtained from a survey of tax rates in 60 countries around the world $^{3}$ provides some general insight showing that for the most part, Turkey's level of corporate tax is not significantly different from that of other OECD countries and those of EU members. Although the rates of tax may be comparable, there is inconsistency in the level and application of taxes and tax law, The changes of tax percentages every year create a confidence problem for foreign investors. 


\section{The Role of the Government to Encourage Foreign Investors}

Especially for emerging markets, it is felt that governments have a key role for the promotion of FDI. Key responsibilities of the Turkish government in regards to FDI were highlighted as:

- Maintaining political and economic stability

- Improving Turkey's image abroad

- Providing effective investment incentives.

\section{Political and economic stability}

Foreign capital needs always secure environment. The stable economy and political situation is critical for developing economies wishing to attract FDI. The consistency between the creation of policy and the way it is implemented is also very important. The government needs to take its hands off the economy in regard to providing services best run privately. Through the privatization of state run enterprises, FDI will be encouraged..

\section{Turkey's image abroad}

Turkey's image abroad is one of the most important influences on FDI in Turkey. Turkey must make every effort to change the perceptions of Turkey abroad and to highlight the positive aspects of doing business in this emerging market.

\section{Effective investment incentives}

The Government should have a clear vision of the type of FDI it is trying to attract. Also, Government incentives should be provided to industries where they are needed. The underlying policies of the government are strong but improvement is needed in how FDI policy is implemented. The implementation of FDI law in Turkey is highly bureaucratic. The bureaucratic process needs to be sped up and made more efficient.

The laws to protect intellectual property rights are present but the extent of their enforcement is not adequate. Foreign investors have little or no problem with breaches of intellectual property rights, however there are some problems of copyright law infringements and counterfeiting. 
This view is shared by the Foreign Investors Association of Turkey $\left(\right.$ YASED) ${ }^{4}$ who declares that it is commonly felt that the laws regarding intellectual property rights in Turkey are sufficient by international standards. There is a consensus that the real problem is in the implementation of the applicable laws. YASED feels the state must increase its efforts to aware the public on the issue of intellectual property right violations and the impact that these violations have on Turkey.

The transfer of modern technology from developed MNEs to developing countries is widely seen as one of the most important benefits that FDI brings to a host country. ${ }^{5}$ There are no barriers to technology transfer for new firms doing business and technology can be easily adapted when doing business in Turkey.

\section{Labor Markets and FDI}

Low material and labor costs, according to conventional research, are one of the most important comparative advantages of host countries. Access to a large, young, cheap, highly productive, educated and motivated labor force is one of the key factors that MNEs consider when choosing a country location. As Table 3 shows, Turkey is more expensive than most other developing countries. In regards to the productivity of labor, measured by GDP per working hour, and the "efficiency" of the labor force, Turkey compares less favorably, trailing far behind the levels sustained both by developed countries and also the developing countries. 
Table 3: International Comparison of Labor

Productivity, Cost and Efficiency

\begin{tabular}{|c|c|c|c|c|c|}
\hline \multicolumn{4}{|c|}{ Labor productivity $\quad$ Labor costs } & \multicolumn{2}{|c|}{ Labor efficiency $^{*}$} \\
\hline Country & \$/hour & Turkey $=100$ & \$/hour & Turkey $=100$ & Turkey $=100$ \\
\hline Indonesia & 1.16 & 28 & 0.09 & 2 & 1400 \\
\hline Russia & 2.27 & 54 & 1.15 & 22 & 245 \\
\hline Hungary & 7.09 . & 170 & 1.40 & 27 & 630 \\
\hline Mexico & 5.92 & 142 & 1.52 & 29 & 490 \\
\hline Czech Republic & 5.15 & 124 & 1.64 & 31 & 400 \\
\hline Philippines & 1.03 & 25 & 1.78 & 34 & 74 \\
\hline China & 0.68 & 16 & 2.11 & 40 & 40 \\
\hline Malaysia & 3.68 & 93 & 2.59 & 49 & 190 \\
\hline Chili & 6.02 & 144 & 4.74 & 90 & 160 \\
\hline South Korea & 6.70 & 160 & 4.89 & 93 & 172 \\
\hline Taiwan & 12.31 & 295 & 5.07 & 97 & 304 \\
\hline Portugal & 12.40 & 297 & 5.15 & 98 & 303 \\
\hline Singapore & 22.26 & 534 & 7.32 & 140 & 381 \\
\hline Greece & 16.54 & 396 & 7.81 & 149 & 266 \\
\hline Israel & 21.87 & 524 & 10.93 & 208 & 252 \\
\hline Spain & 22.75 & 545 & 11.92 & 227 & 240 \\
\hline Australia & 23.72 & 569 & 13.54 & 258 & 221 \\
\hline Canada & 21.78 & 522 & 15.46 & 295 & 177 \\
\hline France & 36.32 & 871 & 17.79 & 339 & 257 \\
\hline USA & 33.57 & 805 & 18.24 & 348 & 231 \\
\hline Luxembourg & 48.80 & 1170 & 19.23 & 366 & 320 \\
\hline Japan & 32.13 & 771 & 20.66 & 394 & 196 \\
\hline Belgium & 38.25 & 917 & 22.51 & 429 & 214 \\
\hline Switzerland & 36.39 & 872 & 24.22 & 462 & 189 \\
\hline Germany & 34.87 & 836 & 27.89 & 532 & 157 \\
\hline Average & 18.15 & 435 & 9.99 & 190 & 229 \\
\hline Turkey & 4.17 & 100 & 5.24 & 100 & 100 \\
\hline
\end{tabular}

* Calculated as a ratio of productivity to cost

Source: Confederation of Turkish Employers (TISK) 
When the question turns to more qualitative measures of labor quality, the strengths of Turkish workers in regards to work ethic and trainability are recognized as the general characteristics. The poor quantitative performance of Turkey may be attributed to the level of technological development and productive machinery rather than the quality and efficiency of the Turkish workers.

\section{Infrastructure}

The level of development of a host country's infrastructure is another key variable for FDI.

Overall, investors are happy with the level of telecommunications provided and see the sector as a great opportunity for future FDI in the coming years. Turkey has one of the fastest growing telecommunications sectors in the world in terms of both fixed line growth and GSM penetration. The level of development of the Turkish telecom sector is trailing the rest of Europe in other ways though. Compared to the rest of Europe where there are 4 payphones per 1000 inhabitants, in Turkey there are only 1.3. Another area of weakness is the access to fixed line telecommunications in the rural areas of the country. Investment is needed in this field to bring Turkey's telecom sector up to the standards of its European counterparts. With annual growth rates of over $100 \%$ since 1994, GSM penetration in Turkey is one of the highest in Europe and the world. With a penetration rate of only $13 \%$ in 2000 though, Turkey is far behind the rest of Europe and this allows for a significant level of growth in the near future. The internet industry in Turkey is highly fragmented with currently over 50 ISPs serving the market.

Turkey's supply of energy is not sufficient to meet its increasing demand. With the level of demand projected to rise substantially in the coming future, the building up of the energy infrastructure is an important problem for Turkey. However, with a number of investments such as the Blue Stream project, the East Anatolian natural gas pipeline project and the Turkmenistan pipeline, this problem is aimed to be solved. Overall, although improvements need to be made in regards to infrastructure developments, the level of infrastructure in Turkey is relatively satisfactory. 


\section{Exports}

Exports from Turkey have increased since 1980s. From 1980 to 1990 , exports increased at an average annual rate of 33\% from \$US2.9 billion to \$US12.9 billion ${ }^{6}$. This was stimulated by the EU Customs Union in 1996 but was negatively influenced by crisis in Asia and Russia during 1997 and 1998.

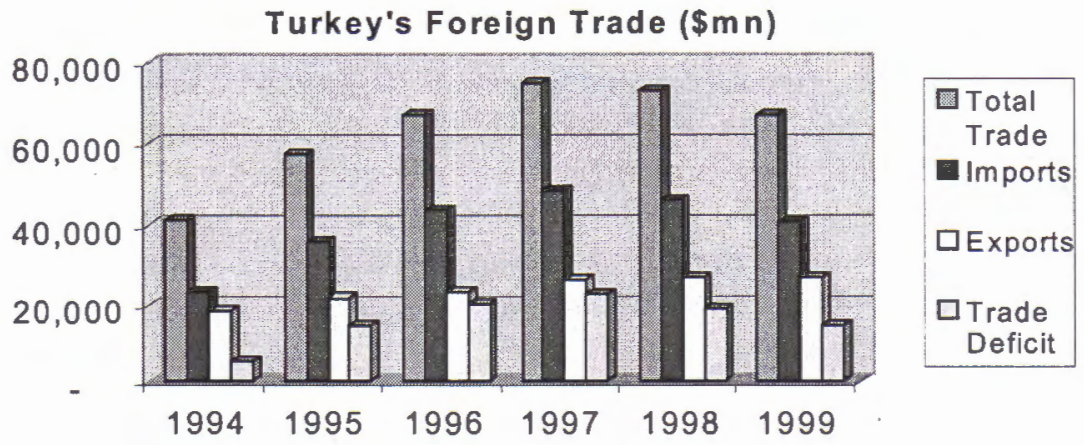

Source: SSI

The regulations for export are quite encouraging in Turkey, and that there are almost no restrictions in regards to the export of products to the EU except agricultural products. The major problem with the system is again the bureaucratic procedures. After the Customs Union with the EU, it was hoped that the bureaucracy would be streamlined, but the heavy paperwork still continues to a certain extent.

\section{Imports}

From 1980 imports have increased from \$US 7.9 billion to approximately \$US 49 billion over the past two decades. The effect of the EU Customs Union on imports was impressive in 1996. The imports increased by $22 \%$ in the first year of the Customs Union.

The competition for FDI is intense around the world. It is important to provide a quick and efficient system for trade in this environment. Eliminating as many deterrents to investment as possible should be the focus of foreign investment policy of the government. 


\section{EU Customs Union}

On January $1^{\text {st }}, 1996$, a Customs Union has been established between the EU and Turkey. There is no doubt regarding the large impact of the Customs Union on the level of trade with Turkey. The levels of imports and exports just before and after the Customs Union are self-explanatory. Exports have increased from $\$ 21.6$ billion in 1995 to $\$ 26$ billion in 1997, and the level of imports rose from $\$ 35.7 \mathrm{bn}$ in 1995 to $\$ 48.5$ in 1997 .

The long-term impact of the union on Turkey will be to strengthen Turkey's competitiveness internationally. Facing competition from abroad, Turkish companies have had to increase both the quality of their products and the efficiency of the processes in which they are made. With these pressures of competition both from abroad and from consumers domestically, Turkish companies are becoming more competitive compared to the rest of the world.

Reforms are still needed. Domestic and foreign exporters in Turkey are expected to increase capacity in order to achieve economies of scale by serving a much wider market.

\section{Positive Effects of the Union}

- Promotes competition

- Improves product quality

- Promotes investments

- Attracts foreign direct investments

- Simplifies procedures

- Lowers customs costs

- Helps the small/ medium sized enterprises

- Enforces implementation of laws

- Reduces trade barriers

- Increases the level of imports and exports

- Increases the choice of products for customers at reduced prices 


\section{The effects of potential EU Membership of Turkey on FDI}

The candidacy of Turkey for full EU membership increased the attention on Turkey. The close relationship of Turkey with the EU will help the convergence of the regulations and standards with the EU, which will also encourage FDI. The Copenhagen criteria are the entrance criteria for all the prospect members, including Turkey. The problems of Turkey for EU membership can be considered as follows:
a) Human rights issues
b) Cultural background differences
c) Regional disparities
d) Difference between the approaches of EU and Turkey on the definition of minority and terrorism.
e) Unstable political and economic environment.
f) Other political problems concerning Cyprus and the Aegean Sea

\section{The Importance of Turkey in the region}

Turkey is the most important country in the Middle East region and a key player in the Mediterranean. Some of the major differentiating characteristics of Turkey are mentioned in the table below.

- Higher purchasing power

- Rich supply of raw materials

- Competitive market

- Young and educated population

- Better quality and productivity

- Greater knowledge base than the rest of the region

- Open and free market

- Comparatively advantageous in manufacturing and assembling

- The culture of Democracy

- Better technology

- Better labor force

- Better infrastructure

- Religious tolerance 


\section{Why Turkey can not attract more FDI?}

Turkey is one of the most open countries to attract FDI. But unfortunately Turkey has not been able to realize large amounts of FDI.

Besides the economic and political instability that has already been mentioned, the weak Turkish Banking system is another problem that has negatively affected the inflow of FDI to Turkey. It has been forecasted that the number of banks in the system could consolidate down to 15 or 20 larger banks in the future. The privatization program will also have a large impact on the sector as the state banks will eventually be privatized. The relatively high costs in Turkey also discourage FDI.

As to the external reasons increased competition for FDI and global events in the 1990s negatively affected the flow of FDI to Turkey.

With globalization, as countries are moving towards openness, the number of nations competing for FDI resources is increasing. As the competition for FDI intensifies, the power of the MNEs is growing. This is pressurizing governments to find ways of differentiating themselves from other markets by creating a favorable environment to invest.

There have also been a number of major global events that had a negative impact on FDI in Turkey. The Tequila crisis in Mexico in 1994, the Asian crisis in 1997-1998 and the Russian crisis in 1998 are amongst the most deteriorating global events. From 1994 to 1999, the average annual growth in FDI was $-2 \%$ for Turkey. There is a connection between these economic downturns and the poor performance of FDI in Turkey. Not only these global events, but also the financial crises of 2000-2001 in Turkey brought into question the stability and the level of risk associated with investing in emerging market economies.

\section{The factors to improve the level of FDI in Turkey}

Turkey should create a better environment for investment to increase the level of FDI it attracts.

a) Existence of a stable political environment and strong and consistent macro-economic policy 
A strong government that can provide political stability and strong and stable macro-economic policy is necessary for the increase of FDI in Turkey. This includes reducing the level of inflation, maintaining a stable currency, and improving the level of the fiscal budget.

\section{b) Modernization of created assets in Turkey}

Turkey must continue to develop the level of its infrastructure regarding transportation, telecommunication, and utilities. Turkey must improve the infrastructure such as the expansion of the network of roads and highways; the establishment of a reliable supply of energy and water; and the development of an extensive telecommunications network that provides cheap and reliable service.

Modernization of created assets also includes a need to upgrade the level of quality of education, training, and intellectual property right. Over the past two decades, Turkey has changed its economic structure that was based on agriculture and textiles to manufacturing and service-based industries. Turkey should invest in high-tech industries in order to further diversify and in order to increase its competitiveness to attract FDI..

\section{c) Effective Investment Incentives with clearly defined objectives}

Investment incentives, is an important factor in the attractiveness of a host country to potential investors. There are some problems inherent in the current system for investment incentives. Turkey needs to communicate more effectively these incentives to current investors and potential investors abroad. Along with this, government bureaucracy is the primary issue to be struggled.

\section{d) Improvement of the image of Turkey}

Turkey needs to undertake a massive promotional effort for the improvement of its image internationally. Through organizations such as the chambers of industry and commerce, the government should be increasing its effort to promote Turkish industry and business around the world. This needs to be a "team" effort and requires the cooperation of government agencies, private industrialists, the media, and NGOs. 


\section{e) Effective implementation of privitization schemes}

Privatization has been a policy of the Turkish government for the past two decades, albeit with not much of a success mainly due to political instability. Privatizations will provide the government with some directly needed funds and will give foreign investors the opportunities to invest in Turkey.

\section{f) Existence of a sound financial sector}

A strong, trusted and efficient banking and financial sector is necessary for economic efficiency. AN accountable and credible financial sector will be a motivating factor for the foreign investors.

\section{Concluding remarks}

Foreign direct investment plays a key role in the evolution of both developed and less developed economies alike. Through the transfer of technology, encouragement of efficiency and increase in trade FDI has an overwhelmingly positive effect on host countries. In the globalized world FDI is especially important for emerging economies like Turkey.

Turkey has a number of strengths that separate it from its neighboring countries such as a favorable location, a large domestic market, and a strong level of economic growth. However, high inflation, an unstable government and a weak banking system have largely inhibited the countries ability to attract substantial levels of investment. In 1999 the level of FDI to developing countries has been around 183 billion dollars. The destination of 117 billion dollars of the total has been the 5 newly industrializing countries in the Far East. Turkey attracted only 817 million dollars in the same year. This figure increased to 1.3 billion dollars in 2000 . It would be instructive to compare this figure with the corresponding FDI flows to some other countries in the same year: 24 billion dollars to Argentina, 39 billion to China, 7.3 billion dollars to Poland, 32.7 billion dollars to Brazil, 12 billion dollars to Mexico, 5.1 billion dollars to the Czech Republic.

Turkey can only increase the level of FDI over the next decade by establishing economic and political stability, developing its created assets, 
using strong investment incentives, promoting itself and its industry abroad, increasing the pace of privatization and improving the financial sector.

\section{Endnotes}

I The classical capital flows theory simply associates FDI with capital transfers between the countries. A company of a country with overvalued currency may carry out FDI in a country with undervalued currency until exchange rates return to equilibrium. Investment occurs up to where marginal rate of return on capital equals the interest rate.

${ }^{2}$ Erdilek, A., (1985), “Turkey's New Open-door Policy of Direct Foreign Investment: A Critical Analysis of Problems and Prospects", Metu Studies in Development, Vol.13, no.1\&2, pp171-191.

3 Survey was taken from KPMG's website located at http://www.tax.kpmg.net/ . This survey provided a comparison of the tax rates of 60 countries, 29 of which were OECD members. It also included most countries located in the Asian pacific and Latin American regions.

${ }^{4}$ See the related article in Insight YASED, Vol. 1 Issue.2, pp.24, October 1999.

5 Bloomstrom and Kokko, Foreign Direct Investment in Developing Countries, 1996

${ }^{6}$ IGEME

\section{Bibliography}

Balasubramanyam, V.N. (1996), Foreign Direct Investment in Turkey, Macmillan Press Ltd., pp.112-129.

Barrell, R. and N. Pain (1997), "Foreign direct investment, technological change and economic growth within Europe", Economic Journal, Vol. 107, pp.1770-1786. 
Bloomstorm, M. and Kokko, A. (1996), The Impact of Foreign Investment on Host Countries, Stockholm, School of Business, 1996.

Buckley, J.P. and Casson, M. (1976), The Future of the Multinational Enterprise, McMillan Press.

Chuntlai (1997), The Location Determinants of Foreign Direct Investments In Developing Countries, School of Economics, The University of Adelaide.

Emerging Turkey 2000, Oxford Business Group, London.

Erdilek, A., (1985), “Turkey's New Open-door Policy of Direct Foreign Investment: A Critical Analysis of Problems and Prospects", Metu Studies in Development, Vol.13, no.1\&2, pp171-191.

Fukuyama, F. (1995), Trust: The Social Virtues and the Creation of Prosperity, London, Hamish Hamilton.

Helleiner, G.K, (1989), "Transnational Corporations and Direct Foreign Investment", Handbook of Development Economics, Volume II, pp.14421471 .

Kindleberger, C.P. (1969), American Business Abroad, Yale University Press.

Öniş, Z. (1994), "Liberalization, Transnational Corporations and Foreign Direct Investment in Turkey: The experience in the 1980s" in Recent Industrialization Experience of Turkey in a Global Context Greenwood Press, pp.91-109.

UNCTAD, (1999), "UNTCAD Trade and Development Report 1999", UNCTAD - Trade and Development Report, 1999:

Veysel Kula ;The Elaboration of the Reasons for the Existence of FDI, in Yapı Kredi Economic Review, vol.7, no.2, Dec. 1996, p.70.

YASED (1999) Insight YASED, Vol.1, 24 October 


\section{Web Sources}

World Trade Organization

Turkish treasury

World Bank

KPMG Consulting

Turkish Ministry of Foreign Trade

YASED - Turkish Foreign Investors

Association

International Monetary Fund www.wto.org

www.treasury.gov.tr

www.worldbank.org

www.tax.kpmg.net

www.foreigntrade.gov.tr

www.yased.org.tr

www.imf.org 